Ekonomia - Wroclaw Economic Review 22/2 (2016)

Acta Universitatis Wratislaviensis

No 3733

DOI: 10.19195/2084-4093.22.2.1

\title{
Łukasz Jasiński
}

Uniwersytet Marii Curie-Skłodowskiej w Lublinie

lukasz.jasinski@poczta.umcs.lublin.pl

\section{Marta Makowska}

Szkoła Główna Gospodarstwa Wiejskiego w Warszawie

marta_makowska@sggw.pl

\section{Wpływ reformy zdrowotnej \\ w Stanach Zjednoczonych (ObamaCare) na biznes ubezpieczeniowy}

JEL Classification: I11, I13, I18

Keywords: healthcare system, health insurance, ObamaCare

\begin{abstract}
Impact of the Healthcare Reform in the United States (ObamaCare) on the Insurance Business

The main aim of this article is to present the most significant changes for the insurance business that are the result of the reform made by Patient Protection and Affrodable Care Act (commonly known as ObamaCare). The article analyses the specific changes that were introduced into insurance companies activity in order to conform to the requirements of ObamaCare. Moreover, it presents the effects of the changes on the insurers, patients and public institutions.
\end{abstract}

\section{Wprowadzenie}

W 2010 roku przegłosowano w amerykańskim kongresie wejście w życie reformy zdrowotnej. Wprowadzał ją dokument Patient Protection and Affordable Care Act (PPACA), a sama reforma potocznie została nazwana ObamaCare — od nazwiska prezydenta Obamy, który był orędownikiem zmian. Przegłosowanie tej ustawy było historycznym wydarzeniem nie tylko przez rozmiar zmian, jakie miała ona wprowadzić, ale także dlatego, że żaden Republikanin nie zagłosował za tym aktem i przeszła ona głosami samych Demokratów (Oberlander, 2012, s. 2165). Pojawiają

Ekonomia - Wroclaw Economic Review 22/2 (2016)

(C) for this edition by CNS 
się opinie, że żadna socjalna kwestia od wprowadzenia praw człowieka nie budziła tak wielkich emocji i nie prowadziła do takiej polaryzacji poglądów w USA jak właśnie ta reforma (Hall i Lord, 2014, s. g5376). Głównym jej celem miało być zapewnienie dostępu do dobrego ubezpieczenia zdrowotnego dla większej liczby Amerykanów oraz zredukowanie wzrostu kosztów opieki zdrowotnej (Obamacare Facts).

Dla przeciwników reformy jej wprowadzenie oznaczało zwrot w stronę ,socjalistycznej medycyny" (ang. Socialized Medicine).Twierdzili, że państwo będzie w większym stopniu kontrolować rynek, co doprowadzi do tego, że ubezpieczyciele nie będą mogli swobodnie konkurować, wzrosną podatki, podrożeją składki na ubezpieczenie zdrowotne, pracodawcy nie będą mieli wyboru i zostaną zmuszeni, by ubezpieczać swych pracowników. Reforma dla nich była ograniczeniem wolności w medycynie (Huntoon, 2013).

Wiele emocji w tej politycznej dyskusji wywoływały obawy o to, jakie niezamierzone konsekwencje może mieć ta reforma (Hall i Lord, 2014, s. g5376). Oddziaływała ona bowiem na roz maite grupy ludzi (m.in.: seniorów, osoby ubezpieczone i nieubezpieczone, personel medyczny), a także wpływała na funkcjonowanie placówek służby zdrowia oraz na interesy biznesu w rozmaity sposób powiązany z sektorem zdrowotnym.

Niewątpliwie największe zmiany odczuły firmy oferujące ubezpieczenia zdrowotne. Opisanie, jaki wpływ i jakie skutki miała ta reforma na działania i zyski biznesu ubezpieczeniowego, będzie głównym celem tego artykułu. Aby lepiej zrozumieć obecną sytuację amerykańskich firm ubezpieczeniowych oferujących ubezpieczenia zdrowotne (rosnące koszty oraz idące za nimi podwyżki składek) po wprowadzeniu i na zasadach określanych przez ObamaCare, należy w pierwszej kolejności poddać analizie powód, dla którego reforma ta została wprowadzona, czyli chęć zapewnienia osobom ubogim (lub w szerszym znaczeniu osobom dotąd nieubezpieczonym) dostępu do usług medycznych. Istotne dla niniejszego opracowania będzie także omówienie ogólnych zasad funkcjonowania towarzystw ubezpieczeniowych, które wpływają na kształt oferty ubezpieczycieli w postaci prywatnych ubezpieczeń zdrowotnych. Następnie przedstawione zostaną skutki reformy dla branży ubezpieczeniowej (w szczególności dla rynku indywidualnych ubezpieczeń zdrowotnych).

\section{Przyczyny wprowadzenia reformy Obamacare}

Pierwsze pomysły wprowadzenia obowiązkowego ubezpieczenia zdrowotnego w USA (mandatory health insurance, MHI) pojawiły się już na początku XX w. Według amerykańskiego ekonomisty Herberta Emery’ego „MHI zostało uznane za niepotrzebne ze względu na większą zdolność zarobkową amerykańskich robotników. (...) Emery wykazał, że prywatne alternatywy były nie tylko cenowo przystępne, ale również same zarobki wzrosły tam od końca XIX wieku do roku

Ekonomia - Wroclaw Economic Review 22/2 (2016)

(C) for this edition by CNS 
1920" (Steinreich, 2016). Hipotezę Emery'ego o atrakcyjności cenowej rozwiązań rynkowych (takich jak np. stowarzyszenia braterskie funkcjonujące na zasadach samopomocowej firmy ubezpieczeniowej) zdaje się potwierdzać Roderick T. Long (2011) wskazujący, że „na przełomie wieków, średni koszt praktyki lożowej dla pojedynczego członka mieścił się między jednym a dwoma dolarami rocznie. Dzienna płaca mogła opłacić opiekę zdrowotną na rok. Dla porównania: średni koszt usług lekarskich na regularnym rynku wynosił od jednego do dwóch dolarów za wizytę. Mimo to, licencjonowani lekarze, szczególnie ci niekształceni w »renomowanych « szkołach medycznych, zacięcie walczyli o kontrakty z lożami — być może ze względu na bezpieczeństwo jakie oferowały. Ta konkurencja skutecznie zaś utrzymywała koszty na niskim poziomie".

Przed wprowadzeniem ObamaCare amerykański system zdrowotny miał wielu krytyków. Głównym wobec niego zarzutem była duża liczba osób nieposiadających ubezpieczenia (Lofgren, Karpf, Perman, Higdon, 2006, s. 713; Brown, 2008, s. 325). Krytykowano także wysokie i szybko wzrastające koszty opieki zdrowotnej (Lofgren, Karpf, Perman, Higdon, 2006, s. 713; Brown, 2008, s. 325). Interpretacja przez pomysłodawców reformy braku posiadania ubezpieczenia zdrowotnego jak stanu niepożądanego, który prowadzić może do zwiększonych wydatków (na skutek wypadku lub choroby), była jednym z powodów wprowadzenia Patient Protection and Affrodable Care Act (PPACA). Fakt nieposiadania ubezpieczenia zdrowotnego zazwyczaj jest łączony z niskimi dochodami (Harrington C., Estes C., 2008, s. 89, The Kaiser Family Fundation, 2013).

Są jednak badacze, którzy podważają tę tezę. Jak wskazują Goodman, Musgrave i Herrick (2008, s. 315), „,wzrost liczby osób niemających ubezpieczeń ${ }^{1}$ wystąpił w latach dziewięćdziesiątych ubiegłego wieku, w okresie, kiedy wzrastał dochód na głowę i zamożność społeczeństwa". Tabela 1 prezentuje procent osób nieubezpieczonych w różnych grupach dochodów.

Tabela 1. Przedziały dochodów osiąganych przez nieubezpieczonych w USA w 2002 r.

\begin{tabular}{l|c}
\hline Wysokość dochodów (\$) & Osoby nieubezpieczone (\%) \\
\hline Mniej niż 25 000 & 34 \\
\hline $25000-50000$ & 34 \\
\hline $50000-75000$ & 16 \\
\hline 75000 lub więcej & 16 \\
\hline
\end{tabular}

Źródło: opracowanie własne na podstawie Goodman, Musgrave, Herrick (2008, s. 316).

Goodman, Musgrave i Herrick (2008, s. 316-317) dodają także, że „między 1993 i 1999 rokiem liczba nieubezpieczonych wzrosła o 57 procent w go-

1 Z 34,6 mln w 1990 r. do 43,6 mln w 2002 r.

Ekonomia - Wroclaw Economic Review 22/2 (2016)

(C) for this edition by CNS 
spodarstwach mających dochody pomiędzy 50 tysięcy i 75 tysięcy dolarów oraz o 114 procent w tych, które miały wpływy wynoszące 75 tysięcy dolarów i więcej. W przeciwieństwie do tego, w gospodarstwach o dochodach niższych niż 50 tysięcy dolarów liczba nieubezpieczonych zmniejszyła się w przybliżeniu o 2 procent".

Zadać można więc pytanie, jakie jeszcze inne czynniki, oprócz niskich dochodów, mogą zniechęcać do wykupywania ubezpieczenia? Jednym z nich jest niskie ryzyko zachorowania u osób młodych. To nie brak wyobraźni czy odpowiedniej informacji, ale właśnie małe prawdopodobieństwo wystąpienia zdarzenia ubezpieczeniowego jest również istotnym powodem, dla którego część z nich podjęła $\mathrm{w}$ pełni racjonalną decyzję, iż $\mathrm{w}$ razie konieczności skorzystania $\mathrm{z}$ opieki medycznej zapłaci jej cenę rynkową ${ }^{2}$ (Rothbard, 2015, s. 114). Ponadto jeśli ludzkie potrzeby (w tym zdrowotne) zmieniają się wraz z wiekiem, to czy za racjonalne można uznać posiadanie przez osobę młodą i zdrową rozbudowanego oraz kosztownego ubezpieczenia od większości znanych chorób? ${ }^{3}$ Podjęcie decyzji o nieubezpieczeniu należy uznać za racjonalne przede wszystkim z tego powodu, że „działający człowiek wybiera spośród różnych dostępnych mu możliwości. Jedną z nich uznaje za lepszą od pozostałych" (Mises, 2011, s. 80). To właśnie młodzi dorośli stanowili najliczniejszą grupę wśród osób nieubezpieczonych $(27,4 \%)$ (The Keiser Family Fundation za: Makowska, Czerw, 2014, s. 376).

Do niekupowania ubezpieczenia zachęcał także fakt, że przed ObamaCare nie było ono obowiązkowe. Amerykanie mieli prawo nie posiadać ubezpieczenia zdrowotnego.

Będą także osoby, które po prostu nie wiedzą, jak ubezpieczenie kupić, jaka jego forma jest dla nich najlepsza, jak nie dać się oszukać. To może skutecznie zniechęcać do jego wykupienia. Amerykański system ubezpieczenia zdrowotnego jest niezwykle skomplikowany, za co także często jest krytykowany (Makowska, Czerw, 2014, s. 737; Brown, 2008, s. 325).

Należy także podkreślić, że ubezpieczenie nie jest formą dostępu do usług medycznych, ale „tylko” formą finansowania tego dostępu i, co ważniejsze, nie jedyną. Jeśli dana osoba nie zdecyduje się w danym momencie na zakup ubezpieczenia, nie oznacza to jej wykluczenia w razie wystąpienia np. choroby, tylko zmianę formy płatności za usługę medyczną w postaci np. płatności bezpośredniej lub nawet w ostateczności skorzystania z pomocy charytatywnej.

2 W postaci płatności bezpośredniej za usługę.

3 Pytanie to można także poszerzyć. Dlaczego tylko ubezpieczenie zdrowotne miałoby być tak ważne? Na rynku ubezpieczeniowym istnieje przecież wiele rodzajów ubezpieczeń: np. mieszkaniowych czy odpowiedzialności cywilnej w życiu prywatnym. Ich brak także może mieć poważne konsekwencje finansowe dla nieubezpieczonego (np. pożar domu), a jednak nikt nie domaga się wprowadzenia przymusu ich posiadania.

Ekonomia - Wroclaw Economic Review 22/2 (2016)

(C) for this edition by CNS 


\section{Zasady funkcjonowania towarzystw ubezpieczeniowych a ObamaCare}

Odpowiednia selekcja i klasyfikacja ryzyka jest kluczowym elementem przy prowadzeniu biznesu ubezpieczeniowego, w tym także dla ubezpieczycieli oferujących prywatne ubezpieczenia zdrowotne. Istotne w tym kontekście jest odpowiednie zdefiniowanie zdrowia jako przedmiotu ubezpieczenia. Utrata zdrowia (uszczerbek na zdrowiu) musi w kontekście ochrony ubezpieczeniowej (z reguły) nastąpić po zawarciu umowy ubezpieczenia ${ }^{4}$. $Z$ jednej strony ubezpieczyciel może w miarę łatwo określić, czy uszczerbek na zdrowiu nastąpił na skutek nieszczęśliwego wypadku, który zdefiniować można jako zdarzenie zewnętrzne, nagłe, niezależne od ubezpieczonego i przez niego niepożądane. $Z$ drugiej strony pewne trudności może sprawić sprawdzenie, czy uszczerbek na zdrowiu odniesiony wskutek choroby miał miejsce w okresie ochrony ubezpieczeniowej, a nie przed. Ponadto instytucja ubezpieczenia oparta jest na zasadzie wzajemności czy solidarności, co nie oznacza jednak, że wszyscy ubezpieczeni powinni płacić takie same składki. Przykładowo, osoby młode i zdrowe nie generują takiego samego ryzyka zdrowotnego jak osoby starsze. Zatem skoro prawdopodobieństwo uszczerbku na zdrowiu (i tym samym prawdopodobieństwo konsumpcji ubezpieczenia) u osoby młodej jest relatywnie niższe, to składka, jaką ona płaci, powinna to uwzględniać. Jest to tak zwana zasada sprawiedliwości obowiązująca w ubezpieczeniach komercyjnych (Guzel, 2013, s. 99).

Ubezpieczyciele stosują wyłączenia i ograniczenia w ubezpieczeniach zdrowotnych. Gdyby ich nie było, osoby czy grupy reprezentujące „niższe” ryzyko stopniowo rezygnowałyby z ubezpieczenia, ponieważ nie miałyby dostatecznej motywacji do płacenia zawyżonych składek będących efektem zwiększonych kosztów generowanych przez grupy reprezentujące ,wyższe” ryzyko. Co więcej, o ile osoby z obciążeniami zdrowotnymi można zidentyfikować w procesie underwritingu, to identyfikacja tych nadużywających usług medycznych z błahych powodów jest niezwykle trudna (Kostrzewski, 2013, s. 139). Dlatego dla ubezpieczycieli bardzo ważne jest dysponowanie odpowiednimi narzędziami w celu przeciwdziałania zjawisku pokusy nadużycia, charakterystycznego dla rynku ubezpieczeń zdrowotnych. Jest to tym bardziej istotne, że w USA zaledwie $10 \%$ ludności konsumuje około $72 \%$ wydatków zdrowotnych, a osoby tego najbardziej potrzebujące, stanowiące $2 \%$ ludności, ogółem wykorzystują aż 41\% wydatków zdrowotnych (Goodman, Musgrave, Herrick, 2008, s. 276-277).

${ }^{4}$ Oczywiście można wskazać wiele przykładów dopuszczania przez ubezpieczycieli do ubezpieczenia osób, u których uszczerbek na zdrowiu wystąpił przed zawarciem umowy. Może to być efektem prowadzonej przez ubezpieczycieli polityki lub państwowych regulacji. W tym kontekście autorzy mają jednak na myśli podstawowe zasady (ramy), w oparciu o które rozwija się rynek ubezpieczeń (w tym rynek ubezpieczeń zdrowotnych).

Ekonomia - Wroclaw Economic Review 22/2 (2016)

(C) for this edition by CNS 
Udział wydatków na opiekę zdrowotną jako procent PKB jest w USA zdecydowanie wyższy niż w innych krajach i w 2013 r. (rok przed wejściem w życie ObamaCare) wyniósł 16,4\%. Dla porównania następne w kolejności Holandia i Szwajcaria wykazują 11,1\% udział w PKB, średnia dla krajów OECD wynosi z kolei $8,9 \%$, a dla Polski wskaźnik ten jest jeszcze niższy - 6,4\%. Chociaż udział wydatków publicznych w USA jest nieco niższy i wynosi niecałe $8 \%$, nie oznacza to, że pozostała (,prywatna”) część wydatkowana jest bez żadnego wpływu państwa (OECD, 2015, s. 167.). System ochrony zdrowia w Stanach Zjednoczonych czasami mylnie określany jest jako rynkowy, głównie z tytułu wcześniejszego braku przymusu ubezpieczenia. Jednak w rzeczywistości, także przed ObamaCare, był to wielce interwencjonistyczny rynek (Ikeda, 2013) ${ }^{5}$, w tym także dla ubezpieczycieli oferujących prywatne ubezpieczenia zdrowotne. Przykładowo, liczba stanowych regulacji dotyczących ubezpieczycieli wzrosła z 8 w 1965 r. do około 1000 we wczesnych latach dziewięćdziesiątych. (Hoppe, 2006). Wybrane stanowe regulacje wpływające na prywatne ubezpieczenia zdrowotne przedstawione zostały w tabeli 2 .

Tabela 2. Przykładowe regulacje stanowe dotyczące prywatnych ubezpieczeń zdrowotnych w Stanach Zjednoczonych

\begin{tabular}{c|l}
\hline $\begin{array}{c}\text { Liczba stanów, w których } \\
\text { obowiązuje dana regulacja }\end{array}$ & \multicolumn{1}{c}{ Opis regulacji } \\
\hline 49 & ubezpieczenie musi pokrywać koszty leczenia alkoholizmu \\
\hline 45 & ubezpieczenie musi pokrywać koszty wizyt u kręgarza \\
\hline 37 & ubezpieczenie musi pokrywać koszty wizyt u podiatry (podologa) \\
\hline 36 & ubezpieczenie musi pokrywać koszty wizyt u psychologa \\
\hline 27 & ubezpieczenie musi pokrywać koszty leczenia narkomanii \\
\hline 22 & $\begin{array}{l}\text { zakres ubezpieczenia powinien zawierać usługi pracowników } \\
\text { socjalnych (co ma także wpływ na wysokość składki) }\end{array}$ \\
\hline 1 & $\begin{array}{l}\text { ubezpieczenie powinno obejmować konsultacje małżeńskie } \\
\text { w stanie Kalifornia oraz konsultacje duszpasterskie w stanie } \\
\text { Vermont }\end{array}$ \\
\hline 1 & $\begin{array}{l}\text { w stanie Georgia ubezpieczenie musi pokrywać koszty } \\
\text { przeszczepów serca }\end{array}$ \\
\hline 1 & $\begin{array}{l}\text { w stanie Illinois ubezpieczenie musi pokrywać koszty przeszczepu } \\
\text { wątroby }\end{array}$ \\
\hline
\end{tabular}

Źródło: opracowanie własne na podstawie Hoppe (2006), Uncertainty and its exigencies: the critical role of insurance in the free market, https://mises.org/library/uncertainty-and-its-exigencies-criticalrole-insurance-free-market (dostęp: 10.07.2016).

5 Więcej na ten temat: Steinreich (2004).

Ekonomia - Wroclaw Economic Review 22/2 (2016)

(C) for this edition by CNS 
Dodatkowo, oprócz wymienionych wyżej regulacji, ubezpieczyciel mógł odmówić ubezpieczenia osobie, u której zdiagnozowano stan chorobowy w czasie ostatniego roku, natomiast choroby zdiagnozowane wcześniej nie podlegały temu wyłączeniu (Hull, 2011, s. 88). W przypadku niektórych indywidualnych polis ubezpieczyciel nie musiał pokrywać kosztów leczenia chorób, na które cierpiał chory przed podpisaniem polisy (choć zostaną one wykryte po jej podpisaniu); w niektórych Stanach mógł także odmówić ubezpieczenia osób poważnie chorych (Cutomer Guide to Indyvidual Health Insurance za: Makowska, Czerw, 2014, s. 736). Takie regulacje ograniczały więc możliwości odpowiedniej selekcji ryzyka przez ubezpieczycieli, co miało także pewne przełożenie na osiągane przez nich zyski, które stanowiły niewielką część składek ${ }^{6}$ (French, Smith, 2015, s. 61).

$\mathrm{Z}$ perspektywy biznesu ubezpieczeniowego ObamaCare wprowadzało trzy istotne zmiany:

- ubezpieczyciele zostali zobowiązani do objęcia ubezpieczeniem wszystkich chętnych niezależnie od ich stanu zdrowia (historii medycznej). Dodatkowo kalkulacja składek ma być oparta bardziej na wieku i czynnikach geograficznych niż na płci i przede wszystkim historii medycznej ubezpieczonego mogącej wpłynąć na wysokość składki (pre-existing conditions),

- ubezpieczenia zdrowotne muszą spełniać minimalne standardy, to znaczy posiadać odpowiedni zakres (essentials health benefits); ubezpieczyciele nie mogą także stosować elementu współpłacenia (copayements) za indywidualne ubezpieczenia zdrowotne ${ }^{7}$,

- został wprowadzony obowiązek nabycia ubezpieczenia zdrowotnego za wyjątkiem niektórych grup religijnych i tych, których uważa się za niezdolnych do nabycia ubezpieczenia (Murphy, 2013).

Wymogi te sprawiły, że ubezpieczyciele (w celu dostosowania się do wymagań stawianych przez PPACA) musieli anulować część lub większość swoich dotychczasowych programów zdrowotnych ${ }^{8}$, co wprowadziło duże zamieszanie i jednocześnie spotkało się ze społecznym niezrozumieniem oraz niezadowoleniem.

Skala anulacji objęła setki tysięcy osób. Przykładowo Florida Blue zakończyła około 300000 polis, co stanowiło $80 \%$ wszystkich polis ubezpieczyciela w tym stanie. Kaiser Permanente z Kalifornii anulował około 160000 polis - około połowy, jakie ubezpieczyciel posiadał w stanie Kalifornia. Inny ubezpieczyciel, Highmark, anulował około 20\% polis, podczas gdy Independence Blue Cross,

${ }^{6}$ Robinson (2004, s. 18) wskazuje, że zyski dla pięciu największych ubezpieczycieli komercyjnych, w latach 2000-2003 oscylowały w przedziale od -0,8\% do 10,2\% składek, a dla większości wynosiły mniej niż 7\%.

7 Ostatecznie współpłacenie jednak występuje.

8 Niektóre programy mogły być kontynuowane, jednak bez możliwości przyjmowania nowych ubezpieczonych (block closure), a pozostałe musiały zostać całkowicie anulowane. Więcej na ten temat (French, Smith, 2015, s. 69-70).

Ekonomia - Wroclaw Economic Review 22/2 (2016)

(C) for this edition by CNS 
główny ubezpieczyciel w Filadelfii, wycofał około 45\% swoich programów zdrowotnych (Appleby, Gorman, 2013).

Reforma, chociaż miała wpływ na wszystkie rodzaje prywatnych ubezpieczeń zdrowotnych (grupowe - zawierane przez pracodawcę i indywidualne), to największe zmiany wywarła na tym drugim rynku (a zwłaszcza na rynku ubezpieczeń sprzedawanych przez ubezpieczycieli w ramach Healthcare Insurance Marketplace $^{9}$ ). Zmiany te znajdują swoje odzwierciedlenie w statystykach. W $2014 \mathrm{r}$. prywatnym ubezpieczeniem grupowym (pracowniczym) objętych było 55,4\% ludności, a z ubezpieczeń indywidualnych korzystało 14,6\% — o 3,2 \% więcej niż przed rokiem ${ }^{10}$. Było to spowodowane między innymi wymogami formalnymi stawianymi ubezpieczycielom przez PPACA oraz, co ważniejsze, wsparciem finansowym udzielanym przez rząd (ulgi podatkowe, dopłaty do indywidualnych programów ubezpieczeniowych). W efekcie liczba osób nieubezpieczonych zmniejszyła się z 41,8 milionów w 2013 r. do 33 milionów w 2014 r. — zmiana o 10,4\% (U.S. Census Bureau, 2015, s. 3).

\section{Skutki ObamaCare dla rynku ubezpieczeń zdrowotnych}

\subsection{Wzrost składek na rynku indywidualnych ubezpieczeń zdrowotnych (Health Insurance Marketplace)}

Nowe regulacje spowodowały, że do programów ubezpieczeń zdrowotnych zaczęły przystępować osoby, dla których wcześniej nie było to możliwe ze względu na ich stan zdrowia. W konsekwencji ubezpieczyciele musieli ustalać wysokość składek z uwzględnieniem przyszłych kosztów generowanych przez osoby reprezentujące ,wyższe” ryzyko zdrowotne. Efekty tych zmian widoczne są w szczególności na rynku indywidualnych ubezpieczeń zdrowotnych (zawieranych w wariancie jednoosobowym lub rodzinnym), w tym zwłaszcza na Healthcare Insurance Marketplace. W roku 2016 poziom średniej składki wzrósł w większości stanów, co uwzględnione zostało w tabeli 3.

${ }^{9}$ Umożliwia ubezpieczonym zakup ubezpieczenia przez Internet (Healthcare.gov), daje możliwość szybkiego porównania składek oraz skorzystania z rządowych subsydiów, jest nadzorowane federalnie lub/i przez poszczególne stany.

10 Pozostałe formy dostępu do usług medycznych to programy rządowe: Medicaid (19,5\%), Medicare (16\%) i military coverage (4,5\%).

Ekonomia - Wroclaw Economic Review 22/2 (2016)

(C) for this edition by CNS 
Tabela 3. Średni wzrost składek na rynku indywidualnych ubezpieczeń zdrowotnych (Health Insurance Marketplace) w 2016 r.

\begin{tabular}{|c|c|c|c|}
\hline Stan & Średni wzrost składki & Najniższy wzrost & Najwyższy wzrost \\
\hline Minnesota* & 47,7 & 14,2 & 49 \\
\hline Alaska & 39,1 & 38,7 & 39,6 \\
\hline Tennessee* & 35,2 & 0,4 & 36,3 \\
\hline Hawaje & 30 & 27,3 & 34,4 \\
\hline Oklahoma & 29,4 & 21,6 & 34,4 \\
\hline Karolina Północna & 29 & 20 & 32,5 \\
\hline Alabama* & 28,3 & 8,8 & 28 \\
\hline Montana & 26,3 & 22,2 & 34 \\
\hline Wirginia Zachodnia & 24 & 24 & 24 \\
\hline Oregon & 23,2 & 8,3 & 37,1 \\
\hline Missouri* & 23,1 & 9,8 & 29,7 \\
\hline Kansas & 23 & 18,5 & 25,4 \\
\hline Delaware & 22,1 & 16,8 & 22,4 \\
\hline Iowa & 22 & 9,4 & 28,7 \\
\hline Illinois* & 21,9 & 9 & 26 \\
\hline Maryland & 20,6 & $-3,3$ & 26 \\
\hline Idaho & 20,1 & $-8,0$ & 26 \\
\hline Georgia* & 19,2 & 0,9 & 30 \\
\hline Arizona* & 19 & 10,1 & 24,7 \\
\hline Nebraska & 17,9 & 14,8 & 21,9 \\
\hline Utah* & 15,7 & $-0,4$ & 24 \\
\hline Karolina Południowa & 14,9 & 8,7 & 31,8 \\
\hline Pennsylvania & 14,6 & $-2,1$ & 26,2 \\
\hline Teksas* & 14,1 & $-9,2$ & 34 \\
\hline Luizjana & 13,9 & 6,8 & 29,5 \\
\hline Dakota Południowa & 13,5 & 6 & 25 \\
\hline Kolorado & 13,4 & 4 & 30,8 \\
\hline New Jersey* & 13,1 & $-7,3$ & 18 \\
\hline Dakota Północna* & 12,6 & 8,5 & 12,8 \\
\hline Floryda & 9,2 & $-6,9$ & 16,4 \\
\hline Ohio** & 8,8 & $-5,8$ & 32 \\
\hline Nevada & 8,4 & 2,9 & 11,4 \\
\hline Wirginia & 8,04 & $-3,3$ & 14,9 \\
\hline
\end{tabular}

Ekonomia - Wroclaw Economic Review 22/2 (2016)

(C) for this edition by CNS 


\begin{tabular}{l|c|c|c}
\hline Kentucky & 7,5 & -11 & 25,1 \\
\hline New Hampshire* & 7,3 & $-27,5$ & 16,3 \\
\hline Massachusetts** & 6,6 & 1,5 & 20,8 \\
\hline Wisconsin** & 6,5 & $-10,2$ & 20,8 \\
\hline Wyoming* & 6,2 & 6,2 & 6,2 \\
\hline Michigan & 6,1 & $-12,6$ & 20,5 \\
\hline Nowy Jork & 6 & $-10,4$ & 13,2 \\
\hline Vermont & 5,5 & 2,4 & 5,9 \\
\hline Arkansas & 4,6 & $-8,2$ & 7,2 \\
\hline Rhode Island & 4,5 & 2,7 & 5,8 \\
\hline Maine** & 4,1 & $-4,8$ & 18,3 \\
\hline Nowy Meksyk & 3,7 & $-2,7$ & 10,5 \\
\hline Waszyngton & 3,1 & $-12,1$ & 19 \\
\hline Connecticut & 2,2 & $-1,3$ & 7,2 \\
\hline Kalifornia** & 1,5 & 4,6 & 9,7 \\
\hline Indiana & 1 & -19 & 13,5 \\
\hline Missisipi* & $-0,2$ & $-0,2$ & $-0,2$ \\
\hline
\end{tabular}

Źródło: opracowanie własne na podstawie: Freedom Partners (2016), 2016 ObamaCare premium increase tracker, http://freedompartners.org/latest-news/2016-obamacare-premium-increases/ (dostęp: 13.07.2016).

* dane niekompletne, $* *$ dane nieważone.

Według powyższych danych co najmniej dwucyfrowe podwyżki objęły 29 stanów, a tylko w jednym (Missisipi) wystąpiła niewielka obniżka. Dla porównania wskaźnik inflacji w systemie ochrony zdrowia w USA w maju 2016 r. (w porównaniu do maja 2015 r.) wyniósł $3,17 \%{ }^{11}$ (Ycharts, 2016), co oznacza, że dynamika wzrostu składek tylko w pięciu stanach była od niego niższa. Na podobnym poziomie kształtuje się także wskaźnik cen usług medycznych, który wynosił w maju 2016 r. 3,5\% (Bureau of Labor Staistics, 2016).

Badanie The Kaiser Family Fundation z 2014 roku wśród osób nieposiadających ubezpieczenia wskazało, że to wysokość składek dla $48 \%$ stała się główną przyczyną niewykupienia polisy (The Kaiser Family Fundation, 2015). W 2014 roku aż 33 miliony osób wciąż nie posiadały ubezpieczenia (U.S. Census Bureau, 2015, s. 3). Dla ubezpieczycieli jest to istotne, ponieważ im więcej osób ubezpieczonych, tym podwyżka składki zostanie rozłożona na większą grupę (dla pojedynczej osoby będzie zatem mniej odczuwalna). Według szacunków ubezpieczyciele oczekiwali, że do stworzenia odpowiednio licznej grupy ryzyka

11 W długim terminie wskaźnik ten wynosi 5,41\%.

Ekonomia - Wroclaw Economic Review 22/2 (2016)

(C) for this edition by CNS 
potrzeba około 75\% osób kwalifikujących się do Healthcare Insurance Marketplace. Jednak tylko w stanie Vermont ten wskaźnik został osiągnięty. Z kolei w stanie Iowa do ubezpieczenia zarejestrowało się tylko $20 \%$ osób (Goodman, 2015). Między innymi na tej podstawie już w 2015 r. ostrzegano przed wzrostem składek. Przykładowo w stanie Oregon, gdzie do ubezpieczenia przystąpiło mniej niż 35\% osób się do niego kwalifikujących, Moda, ubezpieczyciel z największym udziałem w rynku (52\%), poprosił o 25,6\% podwyżkę składki. Inny ubezpieczyciel - Lifewise (19\% udziału w rynku) poprosił z kolei możliwość podniesienia składki o 38,5\%. Podobna sytuacja miała miejsce w pozostałych stanach (Laszewski, 2015).

Co więcej, składki w roku 2017 prawdopodobnie także znacząco się zwiększą z uwagi na fakt, że Obmacare nie zdołało zachęcić wielu młodych ludzi do płacenia wyższych składek. Ponadto w 2017 r. wygasają dwa programy pokrywające część kosztów ubezpieczycieli przez rząd federalny (Mitchell, 2016).

Programy te miały z założenia pomóc ubezpieczycielom utrzymywać składki na przystępnym poziomie, co ostatecznie zakończyło się niepowodzeniem. Pierwszy z nich pokrywa koszty ubezpieczycieli, jeśli te dla danego ubezpieczonego przekroczyły 45000 dolarów rocznie (w 2014 r. było to 80\% kosztów, jednak do limitu 250000 dolarów). Drugi program, tak zwany risk corridor, pokrywa pozostałe straty ubezpieczycieli na podstawie odpowiedniej formuły. Przykładowo jeśli okaże się, że koszty ubezpieczyciela będą w danym roku wyższe niż zakładał, wówczas około $75-80 \%$ dodatkowych kosztów pokryje ponownie rząd, a de facto podatnicy. Może to także spowodować, że ubezpieczyciele nie będą skłonni do odpowiednio wysokich podwyżek, obawiając się utraty klientów i jednocześnie mając pewność pokrycia części strat przez państwo. Według szacunków Congressional Budget Office w ciągu następnej dekady około 1,071 biliona dolarów zostanie za pomocą tych dwóch programów przetransferowane od podatników do firm ubezpieczeniowych (Salerno, 2016).

\subsection{Pojawienie się współpłacenia}

Dodatkowo, chociaż początkowo tego nie zakładano, na rynku Healthcare Insurance Marketplace pojawił się element współpłacenia (copayement) — ubezpieczony musi ponieść część wydatków (odgórnie ustalony przez ubezpieczyciela roczny limit) i dopiero, w następnej kolejności, pozostałe koszty pokrywa ubezpieczyciel ${ }^{12}$. Przed reformą wysoki poziom współpłacenia zmniejszał koszty ubezpieczyciela, który mógł tym samym obniżyć ubezpieczonemu składkę. I vice versa, niski poziom współpłacenia lub jego brak wiązał się z wyższą składką. Można zatem mówić o negatywnej korelacji składki i współpłacenia. Tymcza-

12 Ubezpieczony ma jednak możliwość obniżenia kosztów współpłacenia poprzez uczestnictwo w tak zwanym Cost Sharing Reduction (CSR), jednak jest to możliwe tylko w przypadku ubezpieczenia w wariancie srebrnym (Obamacare Facts, brak daty).

Ekonomia - Wroclaw Economic Review 22/2 (2016)

(C) for this edition by CNS 
sem po wprowadzeniu ObamaCare występuje korelacja pozytywna - relatywnie wyższe poziomy współpłacenia nie spowodowały obniżenia składek — wręcz przeciwnie, ich poziom wciąż rośnie. Wysokość poziomu współpłacenia zależy między innymi od rodzaju i formy programu ubezpieczeniowego i może wynosić kilka, kilkanaście lub nawet kilkadziesiąt tysięcy dolarów rocznie, powodując, że wiele osób nie jest w stanie zapłacić za leczenie (Cannon, 2015).

\subsection{Ulgi podatkowe dla ubezpieczonych}

Dla ubezpieczycieli równie istotny, choć bezpośrednio niewpływający na ich zyski, jest także program ulg podatkowych przyznawanych osobom, które nabędą ubezpieczenie za pomocą Healthcare.gov. W roku 2016 zarejestrowanych w ten sposób było 8,52 miliona osób, z czego $83 \%$ kwalifikowało się do otrzymania ulgi podatkowej. Średnia wysokość składki wyniosła 408 dolarów miesięcznie przed naliczeniem ulgi, która stanowiła 294 dolary, obniżając wysokość składki do 113 dolarów miesięcznie (72-procentowa redukcja składki) (U.S. Department of Health and Human Services, 2016, s. 4). Jednak z drugiej strony nie wolno zapominać, że odbyło się to kosztem innych grup społecznych ponoszących w ostateczności koszty finansowe takich programów. Łączenie grup o ,niskim” ryzyku zdrowotnym (ludzie młodzi) z grupami o „wyższym” ryzyku zdrowotnym w jedną całość prowadzi do zawyżenia składek dla pierwszej grupy i jednocześnie do ich zaniżenia dla drugiej grupy. To dlatego większość nieubezpieczonych stanowią ludzie młodzi o niewielkim ryzyku uszczerbku na zdrowiu (Staib, 2009). Jest to także istotny powód, dla którego firmy ubezpieczeniowe będą dalej lobbować w celu utrzymania finansowania przez rząd wyżej wspomnianych programów, ponieważ ich akcjonariusze i pracownicy są ich głównymi beneficjentami (MacKenzie, 2015).

\subsection{Spirala śmierci}

Jako główną i często komentowaną konsekwencję wprowadzenia ObamaCare uznaje się zwiększone prawdopodobieństwo wystąpienia tak zwanej spirali śmierci (death spiral), zjawiska, które zaczyna się od ubezpieczenia osób z „wyższym” ryzykiem zdrowotnym (np. już chorujących) ${ }^{13}$, co prowadzi do wzrostu kosztów. W następnej fazie ubezpieczyciel na skutek rosnących kosztów (a jak to zostało wspomniane wcześniej, relatywnie niewielka liczba ubezpieczonych jest w stanie wygenerować większość kosztów) podnosi składki ubezpieczeniowe, jednak dla niektórych ubezpieczonych (głównie dla osób młodych) stają się one zbyt wysokie w stosunku do ryzyka zdrowotnego, jakie reprezentują. W efekcie rezygnują oni z ubezpieczenia. Rezygnacja części ubezpieczonych powoduje, że ubezpieczyciel traci część przychodów, z których pokrywane są rosnące koszty i aby zrównoważyć

13 Może to nastąpić na przykład na skutek błędów ubezpieczyciela lub właśnie nakazów stawianych przez państwowe regulacje.

Ekonomia - Wroclaw Economic Review 22/2 (2016)

(C) for this edition by CNS 
tę dysproporcję, kolejny raz podnosi wysokość składek. Sytuacja taka prowadzi do kolejnych rezygnacji z ubezpieczenia i kolejny raz ubezpieczyciel musi podnieść składki, aby pokryć koszty. Na końcu tego procesu ubezpieczone pozostają już tylko osoby najbardziej zdeterminowane, to znaczy o wysokim ryzyku zdrowotnym (np. osoby starsze, chorujące), ale w ostateczności nawet one nie są w stanie płacić coraz wyższych składek. Ubezpieczyciel musi zatem ograniczyć negatywną selekcję, czyli poprawić jakość oceny ryzyka, jeśli chce dalej pozostać na rynku. Dlatego jako główną przyczynę zaistniałej sytuacji wskazuje się wymogi stawiane przez ObamaCare (np. obowiązek przyjmowania do ubezpieczenia osób chorych), co doprowadziło do zwiększenia się podatności programów zdrowotnych na negatywną selekcję i rozpoczęło proces spirali śmierci.

\subsection{Wycofywanie się ubezpieczonych}

Na początku czerwca podano, że z końcem marca 2016 r. z indywidualnego ubezpieczenia zdrowotnego (zawartego wcześniej poprzez healthcare.gov) zrezygnowało 1,6 miliona osób, zmniejszając liczbę ubezpieczonych w tym programie z 12,7 do 11,1 milionów, co stanowiło spadek o 13\% (Kaiser Health News, 2016). Część z nich podjęła tę decyzję pomimo świadomości poniesienia kar finansowych z tytułu braku posiadania ubezpieczenia. Przykładowo w 2016 r. osoba nieposiadająca ubezpieczenia zapłaci co najmniej 695 dolarów kary. Szczegółowe informacje dotyczące kar finansowych za brak ubezpieczenia przedstawia tabela 4.

Tabela 4. Limity kar finansowych za brak ubezpieczenia zdrowotnego

\begin{tabular}{c|c}
\hline Rok & $\begin{array}{c}\text { Wysokość kary za brak ubezpieczenia w zależności } \\
\text { od posiadanego wariantu ubezpieczenia (\$) }\end{array}$ \\
\hline 2014 & $\begin{array}{l}\text { 95 za osobę dorosłą, 47,50 za dziecko (do 18 roku życia), 285 za całą rodzinę lub } \\
1 \% \text { dochodów gospodarstwa domowego (zapłacona zostanie wyższa z tych kwot) }\end{array}$ \\
\hline 2015 & $\begin{array}{l}325 \text { za osobę dorosłą, 162,50 za dziecko (do 18 roku życia), 975 za całą rodzinę lub } \\
1 \% \text { dochodów gospodarstwa domowego (zapłacona zostanie wyższa z tych kwot) }\end{array}$ \\
\hline 2016 & $\begin{array}{l}695 \text { za osobę dorosłą, 347,50 za dziecko (do 18 roku życia), 2085 za całą rodzinę lub } \\
2,5 \% \text { dochodów gospodarstwa domowego (zapłacona zostanie wyższa z tych kwot) }\end{array}$ \\
\hline
\end{tabular}

Źródło: opracowanie własne na podstawie: Healthcare.gov, The fee for not having health insurance, https://www.healthcare.gov/fees/fee-for-not-being-covered/ (dostęp: 13.07.2016).

Sytuację dodatkowo pogarsza fakt, że nowe zapisy do ubezpieczenia w ramach Helathcare Insurance Marketplace na 2017 r. zaczynają się dopiero 1 listopada 2016 r. (potrwają do 31 stycznia 2017 r.) (Helathcare.gov), co powoduje, że ubytek 1,6 miliona osób nie może zostać na bieżąco (przynajmniej częściowo) uzupełniony nowymi ubezpieczonymi.

Ekonomia - Wroclaw Economic Review 22/2 (2016)

(C) for this edition by CNS 


\subsection{Rosnące koszty i straty ubezpieczycieli}

19 kwietnia 2016 decyzję o wyjściu z rynku (Healthcare Insurance Marketplace) do końca 2017 r. podjął największy ubezpieczyciel w USA (47,7 milionów klientów), UnitedHealth, obsługujący ubezpieczenia zdrowotne w ramach ObamaCare w 16 stanach (około 795000 klientów). UnitedHealth szacuje starty na około 650 milionów dolarów za sam 2016 r. (Bloomberg, 2016). Wcześniej ubezpieczyciel opuścił America's Health Insurance Plans (AHIP), grupę lobbingową złożoną z firm ubezpieczeniowych, wspierającą ObamaCare ${ }^{14}$. Wyjście z rynku w 2017 r. w co najmniej dwóch stanach (Alabama, Wirginia) zapowiada także Humana, dotychczas oferująca ubezpieczenia w ramach ObamaCare w 15 stanach (554 300 ubezpieczonych) (Bloomberg, 2016). Sytuacja taka powoduje zmniejszenie się liczby dostawców usług medycznych oraz rodzi pewne ryzyko, że dotychczasowi ubezpieczeni, przechodząc do innych ubezpieczycieli, staną się dla nich równie kosztowni.

\section{Wnioski}

Porównując obecną sytuację osób nieubezpieczonych z tą sprzed reformy, można stwierdzić, że na skutek rosnących składek (i relatywnie wyższego poziomu współpłacenia niż przed reformą) nie uległa ona poprawie, a jest nawet gorsza. Idea ubezpieczenia polega na pewnym solidaryzmie, który w warunkach ukształtowanych przez ObamaCare bardzo trudno będzie osiągnąć. Jak ujął to Ludwig von Mises (2000, s. 146), ,zastosowane środki interwencjonistyczne prowadzą do stanu, który, z punktu widzenia tych, którzy interwencjonizm rekomendują, jest ostatecznie mniej pożądany, od tego, który usiłowano zmienić", a ObamaCare w kontekście interwencjonizmu przebiegało według przyjętych wzorców. Według Follanda, Goodmana i Stano (2011, s. 717), ,interwencja przejawia się głównie w trzech działaniach: dostarczania dóbr i usług, redystrybucji i regulacji. Rządy podejmują każde z tych działań w ekonomii zdrowia". Założeniem reformy było zapewnienie osobom ubogim (nieubezpieczonym) dostępu do opieki medycznej, co z kolei pociągało za sobą odpowiednią redystrybucję za pomocą programów ubezpieczeń zdrowotnych. Aby to jednak było możliwe, w pierwszej kolejności należało wprowadzić odpowiednie regulacje zmieniające funkcjonowanie ubezpieczycieli.

Na tej podstawie można oczekiwać zmian w dwóch kierunkach. W pierwszym przypadku wprowadzone regulacje można cofnąć i tym samym umożliwić ubezpieczycielom odpowiednią selekcję ryzyka, co nie tylko poprawi sytuację ich oraz klientów (składki za ubezpieczenia zdrowotne spadną), ale także przyczyni się do rozwoju alternatywnych form finansowania dostępu do usług medycznych. Wyco-

14 Na początku 2016 r. z członkostwa w AHIP zrezygnował także inny ubezpieczyciel Aetna (23,5 miliona klientów). Więcej na ten temat: Bloomberg (2016).

Ekonomia - Wroclaw Economic Review 22/2 (2016)

(C) for this edition by CNS 
fanie ObamaCare wiązałoby się także niewątpliwie z utratą ulg podatkowych i innych subwencji przez wciąż ubezpieczonych. Dodatkowe finansowanie utraciliby także ubezpieczyciele. Jednak w dłuższej perspektywie zmiany te pozwoliłyby na poprawę sytuacji zarówno osób ubezpieczonych, jak i nieubezpieczonych. Należy także pamiętać, że ObamaCare staje się coraz bardziej kosztowny: dla ubezpieczonych i państwa, czyli podatników, oraz firm ubezpieczeniowych.

W drugim przypadku reformę traktować należy jako projekt polityczny, a wynik zbliżających się wyborów prezydenckich w USA będzie bardzo istotny dla przyszłości tego programu. Istotne w tym kontekście będą także oczekiwania społeczeństwa amerykańskiego. Według badania Gallupa z maja 2016 r. (Gallup, 2016), ,58\% badanych Amerykanów popiera zastąpienie PPACA ubezpieczeniem finansowanym ze środków federalnych, które obejmowałoby wszystkich Amerykanów, zaś 37\% sprzeciwia się temu pomysłowi, a 5\% nie ma zdania”. Badanie to, chociaż o niczym nie przesądza, może dosyć dobrze zobrazować zmiany, jakie pod wpływem programów socjalnych dokonały się w amerykańskim społeczeństwie na przestrzeni dekad. Pettergew i Vance (2014) wskazują, że ,urok darmowości jest tak potężny, że niepokojąco dużo ludzi woli przyjąć rolę podopiecznych w państwie opiekuńczym, aniżeli pokierować aktywnie swoim losem. Ekonomista Nicholas Eberstadt z American Enterprise Institute uważa, że Amerykanie stali się narodem roszczeniowym, co stanowi poważne zagrożenie dla charakterystycznej cechy amerykańskiego ducha, jaką była przez wieki samodzielność".

Prawdopodobieństwo zastąpienia ObamaCare ubezpieczeniem finansowanym w całości ze środków federalnych wzrośnie jeszcze bardziej, jeśli w nadchodzących wyborach zwycięży Hillary Clinton, kandydatka demokratów, która już w połowie lat dziewięćdziesiątych ubiegłego wieku była jednym z orędowników wprowadzenia takiego systemu (nazwanego od jej imienia HillaryCare) ${ }^{15}$. Jednak wprowadzenie powszechnego ,ubezpieczenia” z punktu widzenia problemów gospodarki i poziomu zadłużenia publicznego Stanów Zjednoczonych oraz kosztów, jakie wygenerował mniej ,ambitny” ObamaCare, wydaje się co najmniej kontrowersyjne.

\section{Bibliografia}

Appleby J., Gorman A. (2013), Thousands of consumers get insurance cancellation notices due to health law changes, http://khn.org/news/cancellation-notices-health-insurance/ (dostęp: 10.07.2016).

Bloomberg (2016), Aetna follows UnitedHealth in quitting industry group AHIP, http://www. bloomberg.com/news/articles/2016-01-05/aetna-follows-unitedhealth-in-quitting-industry-group-ahip (dostęp: 13.07.2016).

Bloomberg (2016), Humana echoes ObamaCare warning following UnitedHealth exits, http://www. bloomberg.com/news/articles/2016-05-05/humana-echoes-obamacare-warning-following-unitedhealth-exits (dostęp: 13.07.2016).

15 Więcej na temat krytyki HillaryCare: Rothbard (2015, s. 113-118).

Ekonomia - Wroclaw Economic Review 22/2 (2016)

(C) for this edition by CNS 
Bloomberg (2016), UnitedHealth to exit ObamaCare in 16 states to stem losses, http://www.bloomberg. com/news/articles/2016-04-19/unitedhealth-profit-beats-estimates-fueled-by-tech-unit-optum (dostęp: 13.07.2016).

Brown L.D. (2008), The amazing noncollapsing US health care system - is reform finally at hand?, „New England Journal of Medicine”, nr 358 (4), s. 325-327.

Bureau of Labor Statistics (2016), Consumer price index for all urban consumers (CPI-U): U.S. city average, by expenditure category, http://www.bls.gov/news.release/cpi.t01.htm (dostęp: 13.07.2016).

Cannon M.F. (2015), Affordable care: higher premiums, higher deductibles, worse healthcare, https://fee.org/articles/affordable-care-higher-premiums-higher-deductibles-worse-healthcare/ (dostęp: 13.07.2015).

Folland S., Goodman A.C., Stano M. (2011), Ekonomia zdrowia i opieki zdrowotnej, przeł. Magdalena Korona, Marta Siciarek, Warszawa.

Freedom Partners (2016), 2016 ObamaCare premium increase tracker, http://freedompartners.org/ latest-news/2016-obamacare-premium-increases/ (dostęp: 13.07.2016).

French H.E., Smith M.P. (2015), Anathomy of a slow-motion health insurance dath spiral, „North American Actuarial Journal", nr 19 (1), s. 60-72.

Gallup (2016), Majority in U.S. support idea of fed-funded healthcare system, http://www.gallup.com/poll/191504/majority-support-idea-fed-funded-healthcare-system.aspx (dostęp: 14.07.2016).

Goodman J.C. (2015), Are the (ObamaCare) exchanges headed toward a death spiral?, http://www. forbes.com/sites/johngoodman/2015/06/23/are-the-obamacare-exchanges-headed-toward-a-death-spiral/\#2de90c946cfd (dostęp: 13.07.2016).

Goodman J.C., Musgrave G.L., Herrick D.M. (2008), Jak uzdrowić stużbę zdrowia? Raport o światowych systemach opieki zdrowotnej, przel. Krzysztof Węgrzecki, Warszawa.

Guzel Z. (2013), Organizacja i uczestnicy procesu ryzyka, [w:] Medycyna ubezpieczeniowa. Underwritting. Orzecznictwo. Ubezpieczenia zdrowotne, red. Z. Guzel, D.M. Fal, A. Lipka, Warszawa.

Hall M.A., Lord R. (2014), ObamaCare: what the Affordable Care Act means for patients and physicians, „British Medical Journal”, nr 349 (7), s. g5376-g5376.

Harrington C., Estes C. (2008), Health policy: crisis and reform in the US health care delivery system, USA.

Healthcare.gov (brak daty), The fee for not having health insurance, https://www.healthcare.gov/ fees/fee-for-not-being-covered/ (dostęp: 13.07.2016).

Healthcare.gov (brak daty), Open enrollment period, https://www.healthcare.gov/glossary/open-enrollment-period/ (dostęp: 15.07.2016).

Hoppe H.H. (2006), Uncertainty and its exigencies: the critical role of insurance in the free market, https://mises.org/library/uncertainty-and-its-exigencies-critical-role-insurance-free-market (dostęp: 10.07.2016).

Hull J.C. (2011), Zarządzanie ryzykiem instytucji finansowych, przeł. Bartosz Sałbut, Warszawa.

Huntoon L.R. (2013), The Affordable Care Act: a planned transition to socialized medicine, „Journal of American Physicians and Surgeons", nr 18 (4), s. 98-100.

Ikeda S. (2013), Siedem ktamstw o wolnym rynku, www.mises.pl/blog/2013/12/17/ikeda-siedem-klamstw-o-wolnym-rynku/ (dostęp: 10.07.2016).

Kaiser Health News (2016), Drop-out rate for those covered by health law slightly higher than predicted, http://khn.org/morning-breakout/drop-out-rate-for-those-covered-by-health-law-slightly-higher-than-predicted/ (dostęp: 13.07.2016).

Kostrzewski P. (2013), Proces oceny ryzka w ubezpieczeniach zdrowotnych, [w:] Medycyna ubezpieczeniowa. Underwritting. Orzecznictwo. Ubezpieczenia zdrowotne, red. Z. Guzel, D.M. Fal, A. Lipka, Warszawa.

Ekonomia - Wroclaw Economic Review 22/2 (2016)

(C) for this edition by CNS 
Laszewski R. (2015), Why are the 2016 ObamaCare rate increases so large?, http://www. forbes.com/sites/realspin/2015/06/10/why-are-the-2016-obamacare-rate-increases-so-large/\#64bdde16194b (dostęp: 13.07.2016).

Lofgren R., Karpf M., Perman J., Higdon C.M. (2006), The US health care system is in crisis: implications for academic medical centers and their missions, „Academic Medicine”, nr 81 (8), s. 713-720.

Long R.T. (2011), Jak państwo rozwiąało kryzys stużby zdrowia, http://mises.pl/blog/2011/04/20/ long-jak-panstwo-rozwiazalo-kryzys-sluzby-zdrowia/ (dostęp: 09.07.2016).

MacKenzie D.W. (2015), Can we afford "Affordable Care"?, https://fee.org/articles/can-we-afford-affordable-care/ (dostęp: 13.07.2016).

Makowska M., Czerw A. (2014), Reforma systemu ubezpieczeń zdrowotnych w Stanach Zjednoczonych. Zmiany wprowadzane przez Obamacare, „Hygeia Public Health”, nr 49 (4), s. 733-741.

Mises L. von (2000), Interwencjonizm, przeł. Agnieszka Łaska, Jan M. Małek, Kraków.

Mises L. von (2011), Ludzkie działanie. Traktat o ekonomii, przeł. Witold Falkowski, Warszawa.

Mitchell D.J. (2016), How ObamaCare is destroying healthcare access, https://fee.org/articles/obamacare-strikes-out-on-affordability-savings-coverage/ (dostęp: 13.07.2016).

Murphy R.P. (2013), The Economics of ObamaCare, https://mises.org/library/economics-obamacare (dostęp: 10.07.2016).

Obamacare Facts, Health Insurance Copay (Copayment), http://obamacarefacts.com/health-insurance/copay/ (dostęp: 15.07.2016).

Oberlander J. (2012), The future of Obamacare, „New England Journal of Medicine”, nr 367 (23), s. $2165-2167$.

OECD (2015), Health at a Glance 2015: OECD Indicators, Paris.

Pettergew L.S., Vance C.A. (2014), Ile kosztuje “za darmo”?, przeł. Łukasz Szulim, http://mises.pl/ blog/2014/04/11/pettegrew-vance-kosztuje-darmo/ (dostęp: 14.07.2016).

Robinson J.C. (2004), Consolidation and the transformation of competition in health insurance, „Health Affairs”, nr 23 (6), s. 11-24.

Rothbard M.N. (2015), Ekonomiczny punkt widzenia, przeł. Jan Lewiński, Marcin Zieliński, Warszawa.

Salerno J.T. (2016), What you were never told about ObamaCare, https://mises.org/blog/what-you-were-never-told-about-obamacare (dostęp: 13.07.2016).

Staib E.M. (2009), New regulations will destroy the insurance market, https://mises.org/library/ new-regulations-will-destroy-insurance-market (dostęp: 13.07.2016).

Steinreich D. (2016), Opieka społeczna i wiek emerytalny w Europie i Ameryce Pótnocnej, przeł. Agnieszka Sugier, http://mises.pl/blog/2016/05/12/steinreich-opieka-spoleczna-i-wiek-emerytalny-w-europie-i-ameryce-polnocnej/ (dostęp: 09.07.2016).

Steinreich D. (2004), Real medical freedom, https://mises.org/library/real-medical-freedom (dostęp: 10.07.2016).

The Henry Kaiser Family Fundation (2015), Key Facts about the Uninsured Population, http://files. kff.org/attachment/fact-sheet-key-facts-about-the-uninsured-population (dostęp: 07.07.2016).

U.S. Census Bureau (2015), Health insurance coverage in the United States: 2014, Washington, DC.

U.S. Department of Health and Human Services (2016), Health insurance marketplaces 2016: average premiums after advance premium tax credits in the 38 states using healthcare.gov eligibility and enrollment platform, https://aspe.hhs.gov/pdf-report/health-insurance-marketplaces-2016-average-premiums-after-advance-premium-tax-credits-38-states-using-healthcaregov-eligibility-and-enrollment-platform (dostęp: 13.07.2016).

Ycharts (2016), US Healthcare inflation rate, https://ycharts.com/indicators/us_health_care_inflation_rate (dostęp: 13.07.2016).

Ekonomia - Wroclaw Economic Review 22/2 (2016)

(C) for this edition by CNS 